\title{
A Meta-Analysis on the Correlation Between Measurements of Spatial Tasks and Standardized Tests of Environmental Spatial Abilities
}

\author{
Corina Sas and Nurul Mohd Noor \\ Computing Department, Infolab21 Lancaster University, Lancaster, United Kingdom \\ \{mohdnon1,corina\}@comp.lancs.ac.uk
}

Keywords: large scale spatial abilities, spatial tasks, psychometric tests, metaanalysis

\section{Background and aims}

Previous findings indicate that spatial abilities at different scales of space, e.g. smallscale and large-scale space (Montello and Golledge, 1999, Montello, 1993) are partially dissociated (Hegarty et al., 2006). Traditionally, the attempts to identify and assess these different sets of spatial abilities have focused mostly on small scale spaces, whereas significantly less work has focused on assessing large-scale or environmental spatial abilities. This is unfortunate because the existing psychometric tests for small scale spatial abilities account for only $5 \%$ of the variance in the ability to learn large-scale environments (Hegarty and Waller, 2005) and therefore represent poor predictors of environmental learning (Allen et al, 1996; Waller, 2000, 2005).

Given the limited work on developing standardized measures of environmental spatial abilities, such abilities have been investigated through people's performance on nonstandardized spatial tasks in large scale outdoor spaces (McNamara et al, 2003). A multitude of such tasks have been designed and employed with the intention to measure environmental spatial abilities. However, progress with the development of standardized tests for large scale spatial abilities is currently hindered by a threefold challenge: (i) spatial tasks in large scale spaces are usually complex involving several spatial abilities rather than just one, (ii) several spatial tasks have been employed for assessing the same spatial ability, and (iii) spatial tasks in large scale spaces are strongly coupled with the environment in which they are investigated.

The goal of this meta-analysis is to investigate the relationships between environmental spatial abilities and their measurements, i.e. standardized tests or nonstandardized spatial tasks, with the particular aim to identify those spatial tasks which have been successfully and consistently used to measure a particular environmental spatial ability. Our work has focused on identifying strong relationships between specific spatial tasks and environmental spatial abilities as a preliminary step in a larger research agenda aiming towards the development of standardized tests for measuring environmental spatial abilities. 


\section{Meta-Analysis}

\section{Literature Search and Coding Procedure}

Forty nine papers have been initially selected among the papers published in the last 20 years (or less if the journal is newer) in the following peer-reviewed publications: Journal of Spatial Cognition and Computation, Presence: Teleoperators and Virtual Environments, Journal of Environmental Psychology, Intelligence Journal and Journal of Computer in Human Behavior. In addition, an extensive literature search was conducting using Google Scholar ${ }^{\mathrm{TM}}$, PsychINFO, ERIC, ScienceDirect and ACM Digital Library.

The criteria for a paper to be included in the meta-analysis consist of the provision of (i) information describing the measurement of environmental spatial abilities, and (ii) data on correlations between a pair of measurement of spatial abilities. Among the initially identified 49 papers, only 8 papers met the above criteria and could therefore be included in the meta-analysis. Although the remaining papers met the first criteria, they failed to provide correlational data.

Each selected paper reports complex experimental study with more than one condition. For the purpose of this analysis, each experimental study was broken down into several independent studies, i.e. one for each condition, resulting in a set of 102 distinct studies. A standard system was used to code each of these studies, consisting of author, publication, year, spatial abilities, environment, spatial tasks and correlational data. Correlational data between pair of measurements of environmental spatial abilities and performance on spatial tasks were extracted and used for the computation of the size effect. We employed Cohen's (1988) interpretation of effect size: anything greater than 0.5 is large, between 0.5 and 0.3 is moderate, and between $0.3-0.1$ is small.

\section{Findings}

The environmental spatial abilities captured by these studies include sense of direction, perspective topology, spatial updating, landmark recognition and route traversal. Each of them will be briefly outlined below: Sense of direction is the ability of maintaining awareness of one's orientation in large scale space; Perspective topology is the ability to acquire a two-dimensional representation and to recognize a bird's eye view of the environment; Spatial updating is the ability to keep track of the changing relationship between oneself and external object as one moves through the environment; Landmark recognition is the ability to relate to the landmarks along the routes. In addition, we also considered the small scale spatial abilities which account for variance in environmental learning such as mental rotation, perspective taking and spatial memory (Hegarty et al, 2006): Perspective taking is the ability to identify changes in the point of view of object or oneself with respect to the environment; Spatial memory is the ability to record information about one's environment and spatial orientation, and Mental rotation is the ability to manipulate visual patterns. 


\section{Findings}

The results indicate significant effect size for $46 \%$ of studies, medium effect size for $33 \%$ of studies and low effect size for $20 \%$ of studies. This paper focuses on the description and interpretation of the data leading to high effect size (Table 1).

Table 1: High effect size of correlations between measurements of environmental spatial abilities

\begin{tabular}{|c|c|c|c|c|c|}
\hline Abilities & Author/Year & $\begin{array}{l}\text { Measured by } \\
\text { Spatial Task or } \\
\text { Standardized Test } \\
\end{array}$ & Environment & $\begin{array}{l}\text { Spatial Task/Test or } \\
\text { Self-reported performance on } \\
\text { spatial tasks }\end{array}$ & $\begin{array}{l}\text { Effect } \\
\text { Size }\end{array}$ \\
\hline \multirow[t]{8}{*}{$\begin{array}{l}\text { Sense of } \\
\text { direction }\end{array}$} & Hegarty, 2006 & SBSOD & $\begin{array}{l}\text { Two floor } \\
\text { building with } \\
8 \text { landmarks }\end{array}$ & $\begin{array}{l}\text { Accuracy of direction estimates } \\
\text { to unseen landmarks in a new } \\
\text { environment learnt through } \\
\text { direct experience }\end{array}$ & 1.0361 \\
\hline & \multirow[t]{2}{*}{$\begin{array}{l}\text { Prestopnik, } \\
2000\end{array}$} & \multirow{2}{*}{$\begin{array}{l}\text { Kozlowski \& } \\
\text { Bryant sense of } \\
\text { direction scale }\end{array}$} & \multirow[t]{2}{*}{ NA } & $\begin{array}{l}\text { Survey strategy (self report } \\
\text { measure) }\end{array}$ & 0.8729 \\
\hline & & & & $\begin{array}{l}\text { Familiarity (self report } \\
\text { measure) }\end{array}$ & 0.8471 \\
\hline & Waller,2004 & $\begin{array}{l}\text { Waller sense of } \\
\text { direction scale }\end{array}$ & $\begin{array}{l}\text { Building in a } \\
\text { campus }\end{array}$ & $\begin{array}{l}\text { Accuracy of direction estimates } \\
\text { to unseen landmarks in a } \\
\text { familiar environment }\end{array}$ & 0.8216 \\
\hline & \multirow[t]{4}{*}{ Hegarty, 2006} & \multirow[t]{4}{*}{ SBSOD } & \multirow[t]{4}{*}{$\begin{array}{l}\text { Two floor } \\
\text { building with } \\
8 \text { landmarks }\end{array}$} & $\begin{array}{l}\text { Accuracy of distance estimates } \\
\text { to unseen landmarks in a new } \\
\text { environment learnt through } \\
\text { direct experience }\end{array}$ & 0.7965 \\
\hline & & & & $\begin{array}{l}\text { Map sketching of a new } \\
\text { environment learnt through } \\
\text { direct experience }\end{array}$ & 0.7717 \\
\hline & & & & $\begin{array}{l}\text { Accuracy of direction estimates } \\
\text { to unseen landmarks in a new } \\
\text { environment learnt through } \\
\text { video }\end{array}$ & 0.7231 \\
\hline & & & & $\begin{array}{l}\text { Accuracy of distance estimates } \\
\text { to unseen landmarks in a new } \\
\text { environment learnt through } \\
\text { video }\end{array}$ & 0.5385 \\
\hline \multirow{3}{*}{$\begin{array}{l}\text { Perspective } \\
\text { Topology }\end{array}$} & \multirow[t]{3}{*}{ Waller,2004 } & \multirow{2}{*}{$\begin{array}{l}\text { Time taken for } \\
\text { recognizing the } \\
\text { correct bird's eye } \\
\text { view of a learnt } \\
\text { virtual environment }\end{array}$} & NA & Campus familiarity & 0.8471 \\
\hline & & & \multirow[t]{2}{*}{$\begin{array}{l}\text { Building in a } \\
\text { campus }\end{array}$} & $\begin{array}{l}\text { Accuracy of direction estimates } \\
\text { to unseen landmarks in a } \\
\text { familiar environment }\end{array}$ & 0.6521 \\
\hline & & $\begin{array}{l}\text { Accuracy in } \\
\text { recognizing the } \\
\text { correct bird's eye } \\
\text { view of a learnt } \\
\text { virtual environment }\end{array}$ & & $\begin{array}{l}\text { Accuracy of direction estimates } \\
\text { to unseen landmarks in a } \\
\text { familiar environment }\end{array}$ & 0.6992 \\
\hline
\end{tabular}




\begin{tabular}{|c|c|c|c|c|c|}
\hline Abilities & Author/Year & $\begin{array}{l}\text { Measured by } \\
\text { Spatial Task or } \\
\text { Standardized Test }\end{array}$ & Environment & $\begin{array}{l}\text { Spatial Task/Test or } \\
\text { Self-reported performance on } \\
\text { spatial tasks }\end{array}$ & $\begin{array}{l}\text { Effect } \\
\text { Size }\end{array}$ \\
\hline \multirow[t]{2}{*}{$\begin{array}{l}\text { Spatial } \\
\text { Updating }\end{array}$} & \multirow[t]{2}{*}{ Waller,2004 } & $\begin{array}{l}\text { Accuracy of } \\
\text { direction estimation } \\
\text { to unseen } \\
\text { landmarks in learnt } \\
\text { virtual environment }\end{array}$ & \multirow[t]{2}{*}{$\begin{array}{l}\text { Building in a } \\
\text { campus }\end{array}$} & $\begin{array}{l}\text { Accuracy of direction estimates } \\
\text { to unseen landmarks in a } \\
\text { familiar environment }\end{array}$ & 0.606 \\
\hline & & $\begin{array}{l}\text { Time taken for } \\
\text { direction estimation } \\
\text { to unseen } \\
\text { landmarks in learnt } \\
\text { virtual environment }\end{array}$ & & $\begin{array}{l}\text { Accuracy of direction estimates } \\
\text { to unseen landmarks in a } \\
\text { familiar environment }\end{array}$ & 0.5608 \\
\hline \multirow[t]{5}{*}{$\begin{array}{l}\text { Landmark } \\
\text { recognition }\end{array}$} & \multirow[t]{5}{*}{ Kirasic, 2001} & \multirow{5}{*}{$\begin{array}{l}\text { Correct selection } \\
\text { from } 64 \text { scenes of } \\
12 \text { scenes with the } \\
\text { highest landmark } \\
\text { value }\end{array}$} & \multirow[t]{5}{*}{ NA } & $\begin{array}{l}\text { Accuracy of location indication } \\
\text { of buildings from a previously } \\
\text { studied map }\end{array}$ & 0.8471 \\
\hline & & & & $\begin{array}{l}\text { Accuracy of patterns } \\
\text { abstracted from a figure }\end{array}$ & 0.629 \\
\hline & & & & $\begin{array}{l}\text { Accuracy of } \\
\text { imagined appearance of playing } \\
\text { cards after they are rotated }\end{array}$ & 0.5608 \\
\hline & & & & $\begin{array}{l}\text { Accuracy of gestalt completion } \\
\text { on drawings }\end{array}$ & 0.5385 \\
\hline & & & & $\begin{array}{l}\text { Accuracy of distance ranking to } \\
\text { a set of locations in a shopping } \\
\text { place }\end{array}$ & 0.5385 \\
\hline \multirow[t]{3}{*}{$\begin{array}{l}\text { Perspective } \\
\text { taking- }\end{array}$} & \multirow[t]{3}{*}{$\begin{array}{l}\text { Kozhevnikov, } \\
2006\end{array}$} & \multirow{3}{*}{$\begin{array}{l}\text { Accuracy of } \\
\text { direction estimation } \\
\text { from imagined } \\
\text { orientation }\end{array}$} & \multirow{3}{*}{$\begin{array}{l}\text { Two floor } \\
\text { building with } \\
2 \text { landmark } \\
\text { and } 2 \text { target } \\
\text { building on a } \\
\text { campus }\end{array}$} & $\begin{array}{l}\text { Accuracy of tracing a covered } \\
\text { route on the floor plan of a } \\
\text { learnt environment }\end{array}$ & 0.9526 \\
\hline & & & & $\begin{array}{l}\text { Finding a shortcut from the } \\
\text { ending point to the starting } \\
\text { point of the route, as number of } \\
\text { route segments }\end{array}$ & 0.629 \\
\hline & & & & $\begin{array}{l}\text { Accuracy of direction estimates } \\
\text { to unseen landmarks in a learnt } \\
\text { environment }\end{array}$ & 0.606 \\
\hline \multirow[t]{2}{*}{$\begin{array}{l}\text { Spatial } \\
\text { Memory }\end{array}$} & \multirow[t]{2}{*}{$\begin{array}{l}\text { Ondracek, } \\
2001\end{array}$} & \multirow{2}{*}{$\begin{array}{l}\text { Proportion of } \\
\text { correctly placed } \\
\text { colored chips on a } \\
\text { blank figure, } \\
\text { matching the } \\
\text { colored dots on an } \\
\text { amorphous figure } \\
\text { no longer visible }\end{array}$} & \multirow{2}{*}{$\begin{array}{l}\text { Textual } \\
\text { description of } \\
\text { an } \\
\text { environment, } \\
\text { from survey, } \\
\text { route, and } \\
\text { vantage } \\
\text { perspectives }\end{array}$} & $\begin{array}{l}\text { Proportion of correct } \\
\text { placements on a map of } \\
\text { stickpins representing objects } \\
\text { in an environment }\end{array}$ & 0.7965 \\
\hline & & & & $\begin{array}{l}\text { Proportion of correct } \\
\text { placements on a map of various } \\
\text { locations in respect to the } \\
\text { viewer's vantage point. }\end{array}$ & 0.7668 \\
\hline \multirow[t]{2}{*}{$\begin{array}{l}\text { Mental } \\
\text { rotation }\end{array}$} & \multirow[t]{2}{*}{$\begin{array}{l}\text { Kozhevnikov, } \\
2006\end{array}$} & \multirow{2}{*}{$\begin{array}{l}\text { Accuracy of } \\
\text { identifying } \\
\text { invariants in a pair } \\
\text { of two-dimensional } \\
\text { pictures of rotated } \\
\text { three-dimensional } \\
\text { geometric forms }\end{array}$} & \multirow{2}{*}{$\begin{array}{l}\text { Two floor } \\
\text { building with } \\
2 \text { landmark } \\
\text { and } 2 \text { target } \\
\text { building on a } \\
\text { campus }\end{array}$} & $\begin{array}{l}\text { Accuracy of tracing a covered } \\
\text { route on the floor plan of a } \\
\text { learnt environment }\end{array}$ & 0.6521 \\
\hline & & & & $\begin{array}{l}\text { Accuracy of direction estimates } \\
\text { to unseen landmarks in a learnt } \\
\text { environment }\end{array}$ & 0.5164 \\
\hline
\end{tabular}




\section{Conclusion}

Findings suggest that the most valid tools for assessing environmental spatial abilities are self report-based questionnaires. Indeed, over 30\% of correlations of high size effect occur when environmental spatial abilities are captured through self report measurements of sense of direction. Moreover, the three scales of sense of direction correlate significantly with a large array of spatial tasks. Given the inherent subjectivity charactering self assessment, this is an interesting outcome partly explainable through the hierarchical organization of spatial abilities. Sense of direction is a complex environmental spatial ability encompassing several more basic abilities. We conjecture that the more complex an ability is, the stronger its measurements will correlate with a larger range of spatial tasks. While successful at handling complexity, measurements based on self report are limited in their ability to differentiate between the less complex abilities.

In contrast, WALKABOUT is a standardized test that offers objective measurements of two less complex spatial abilities such as perspective topology and spatial updating whose measurements correlate significantly with the ability to point to unseen locations in familiar environments (Waller, 2005). Although the size effect of such correlations is not as large as the one related to sense of direction, the test is still a successful unique attempt to fill the gap in understanding the cognitive components used in acquiring spatial knowledge of large-scale environments.

Because of the complexity of environmental spatial abilities, their relationship with spatial tasks is particularly difficult to disentangle. Findings indicate that measurements of different abilities correlate significantly with performance on the same tasks, and the same ability correlates significantly with performances on different tasks. Although one to one mapping between the measurement of a given ability and its criterion would be useful, it is more realistic to invest effort in developing novel spatial tasks which require a common set of spatial abilities but differ slightly among each other in aspects which require distinct input from different ability. Thus, succeeding in one such task and failing in another will offer an indirect method of assessing the spatial ability which is required by the first task but not by the second one.

Another interesting result is the complexity of the environments employed in these studies. Although holding high face validity, such complexity considerably challenges the investigation of spatial abilities. We conjuncture that the complexity of the environment is related with the complexity of the spatial tasks, and that by simplifying the environment the tasks could be better controlled and spatial abilities better investigated.

\section{References}

1. Allen, G.L., Kirasic, K.C., Dobson. S.H., Long, R.G. and Beck, S. (1996). Predicting environmental learning from spatial abilities: An indirect route. Intelligence, 22(3), 327-355.

2. Hegarty, M., Montello, D. R., Richardson, A. E., Ishikawa, T., and Lovelace, K. (2006). Spatial abilities at different scales: Individual differences in aptitude-test performance and spatial-layout learning. Intelligence. 34(2), 151-176. 
3. Juhel, J. (1991). Spatial abilities and individual differences in visual information, 15(1), 117-137.

4. Kirasic, K. C. (2000), Age differences in adults' spatial abilities, learning environment layout, and wayfinding behavior, Spatial Cognition and Computation 2, 117-134.

5. Kozhevnikov, M., Motes, M.A., Rasch, B. Blajenkova, O. (2006), Rotation Transformations and How They Predict Spatial Navigation Performance, Applied Cognition Psychology. 20: 397-417

6. Kozlowski, L., Bryant, K. (1977). Sense of direction, spatial orientation, and cognitive maps. Journal of Experimental Psychology, 3, 590-598.

7. Lorelle J. Burton, Gerard J. Fogarty. (2003). The factor structure of visual imagery and spatial abilities, Intelligence 31, 289-318.

8. McNamara, T. P., Rump, B., and Werner, S. (2003). Egocentric and geocentric frames of reference in memory of large-scale space. Psychonomic Bulletin \& Review, 10, 589-595.

9. Montello, D.R. (1993). Scale and multiple psychologies of space. In A.U. Frank and I. Campari (eds.). Spatial information theory: A theoretical basis for GIS. LNCS, 716, 312 321. Springer-Verlag.

10. Montello, D.R. and Golledge, R. (1999) Scale and detail in the cognition of geographic information. Report of Specialist Meeting of the Varenius Project. Santa Barbara, CA, National Center for Geographic Information and Analysis.

11. Ondracek, P., Allen, G. L (2000), Children's acquisition of spatial knowledge from verbal descriptions, Spatial Cognition and Computation 2: 1-30.

12. Prestopnik, J.L, Roskos-Ewoldsen, B. (2000)The relations among wayfinding strategy use, sense of direction, sex, familiarity, and wayfinding ability, Journal of Environmental Psychology 20, 177-191

13. Waller, D. (2005). The WALKABOUT: Using virtual environments to assess large-scale spatial abilities. Computers in Human Behavior, 21, 243-253 